\title{
Determination of Barometric Efficiency and Effective Porosity, Boreholes UE-25 c\#1, UE-25 c\#2, and UE-25 c\#3, Yucca Mountain, Nye County, Nevada
}

By ARTHUR L. GELDON, JOHN D. EARLE, and AMJAD M.A. UMARI

U.S. GEOLOGICAL SURVEY

$$
\text { USES/WRIR--97-4098 }
$$

Water-Resources Investigations Report 97-4098

Prepared in cooperation with the

NEVADA OPERATIONS OFFICE,

U.S. DEPARTMENT OF ENERGY, under

Interagency Agreement DE-Al08-92NV10874






\section{U.S. DEPARTMENT OF THE INTERIOR \\ BRUCE BABBITT, Secretary}

\section{U.S. GEOLOGICAL SURVEY}

Gordon P. Eaton, Director

The use of firm, trade, and brand names in this report is for identification purposes only and does not constitute endorsement by the U.S. Geological Survey.

For additional information write to:

Chief, Earth Science Investigations Program

Yucca Mountain Project Branch

U.S. Geological Survey

Box 25046, Mail Stop 421

Denver Federal Center

Denver, CO 80225-0046
Copies of this report can be purchased from:

U.S. Geological Survey

Information Services

Box 25286

Federal Center

Denver, CO 80225 


\section{DISCLAIMER}

This report was prepared as an account of work sponsored by an agency of the United States Government. Neither the United States Government nor any agency thereof, nor any of their employees, makes any warranty, express or implied, or assumes any legal liability or responsibility for the accuracy, completeness, or usefulness of any information, apparatus, product, or process disclosed, or represents that its use would not infringe privately owned rights. Reference herein to any specific commercial product, process, or service by trade name, trademark, manufacturer, or otherwise does not necessarily constitute or imply its endorsement, recom. mendation, or favoring by the United States Government or any agency thereof. The views and opinions of authors expressed herein do not necessarily state or reflect those of the United States Government or any agency thereof. 


\section{DISCLAIMER}

Portions of this document may be illegible electronic image products. Images are produced from the best available original document. 


\section{CONTENTS}

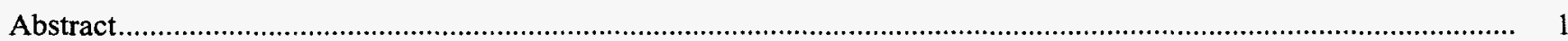

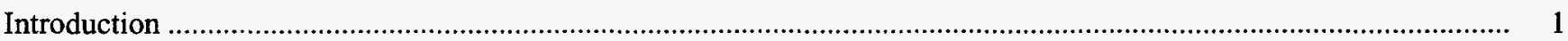

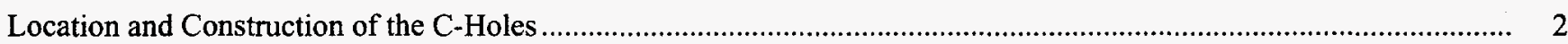

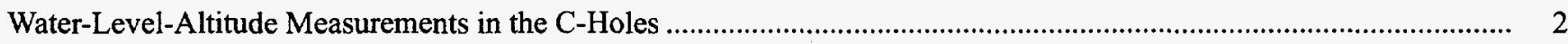

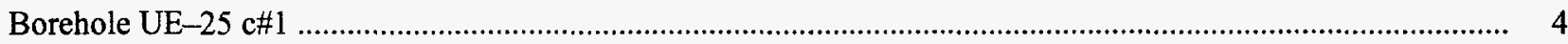

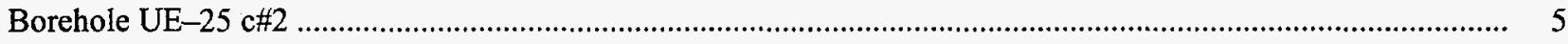

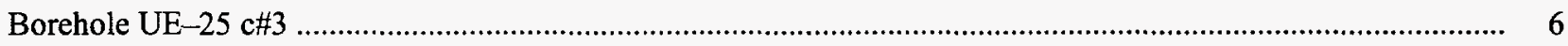

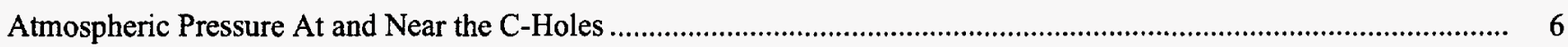

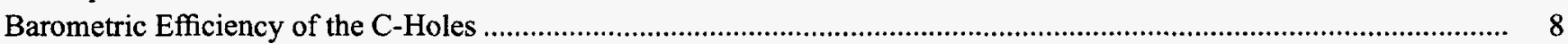

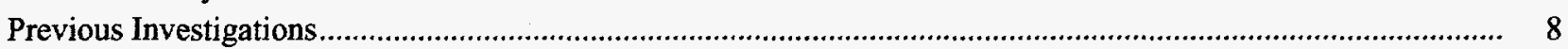



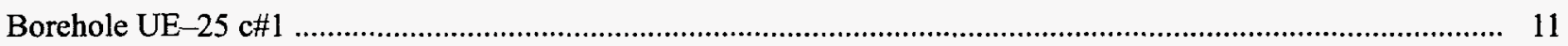

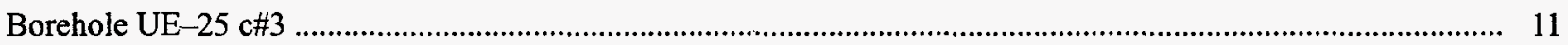

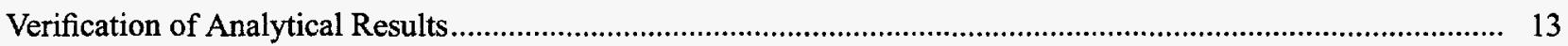

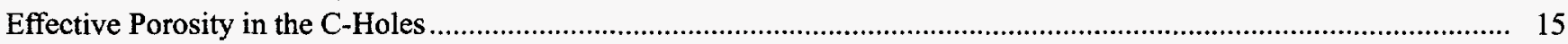

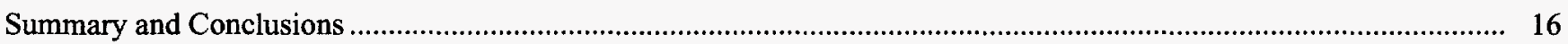

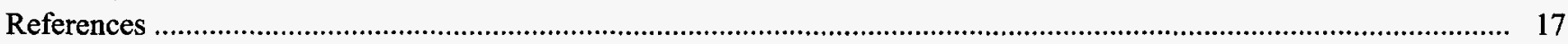

\section{FIGURES}

1. Maps showing location of boreholes UE-25 c\#1, UE-25 c\#2, and UE-25 $\mathrm{c} \# 3$ and weather station WX-3 at Yucca Mountain, Nevada.

2-13. Plots showing:

2. Water-level altitude in borehole UE-25 c\#1, Yucca Mountain, Nevada, July 15 to September 8, 1993 .........

3. Borehole UE-25 c\#2, Yucca Mountain, Nevada: $A$, transducer output, July 15 to September 7, 1993; $B$, water-level altitudes, July 15 to 26,1993 ......

4. Water-level altitude in borehole UE-25 c\#3, Yucca Mountain, Nevada, July 15 to August $17,1993$.

5. Relations of barometric records at borehole UE-25 c\#3 and weather station WX-3, Yucca Mountain, Nevada: $A$, concurrently recorded atmospheric pressures at UE-25 c\#3 and WX-3, July 15 to September 8,$1993 ; B$, regression relation of UE-25 c\#3 barometric data as a function of WX-3 barometric data.

6. Atmospheric pressure at weather station WX-3, Yucca Mountain, Nevada, August 24 to September 5, 1993.

7. Effect of weather-system-related changes in atmospheric pressure on water-level altitudes in borehole UE-25 c\#1, Yucca Mountain, Nevada, July 15 to September 8, 1993

8. Calculated Earth tides at the C-hole complex, Yucca Mountain, Nevada, July 15 to September 7, 1993

9. Measured water-level altitudes and water-level altitudes filtered for frequencies of less than 0.8 cycles

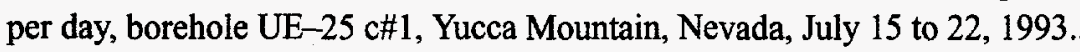

10. Relation of low-frequency water-level-altitude change in borehole UE-25 $\mathrm{c} \# 1$ to low-frequency atmospheric-pressure change at station WX-3, Yucca Mountain, Nevada, July 15 to September 8, 1993 ...

11. Measured water-level altitudes and water-level altitudes filtered for frequencies of less than 0.8 cycles per day, borehole UE-25 c\#3, Yucca Mountain, Nevada, July 15 to 22, 1993.

12. Relation of low-frequency water-level-altitude change in borehole UE-25 c\#3 to low-frequency atmospheric-pressure change at station WX-3, Yucca Mountain, Nevada, July 15 to August 17, 1993

13. Measured water-level altitudes and water-level altitudes corrected for weather-system-related changes in atmospheric pressure, borehole UE-25 c\#1, Yucca Mountain, Nevada, August 24 to September 5, 1993. 


\section{TABLES}

1. Surface coordinates and altitudes of the C-holes and weather station WX-3, Yucca Mountain, Nevada.............. 2

2. Generalized stratigraphy of the $\mathrm{C}$-hole complex, Yucca Mountain, Nevada ....................................................... 4

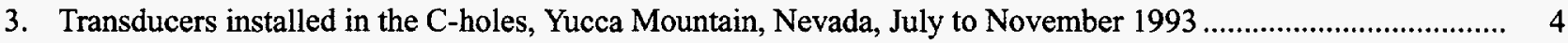

4. Depth-to-water measurements in the C-holes, Yucca Mountain, Nevada, July to November 1993 ...................... 4

5. Periods and frequencies of the principal Earth tides.............................................................................. 11

\section{CONVERSION FACTORS}

\begin{tabular}{rrl}
\hline Multiply & \multicolumn{1}{c}{ By } & To obtain \\
foot $(\mathrm{ft})$ & 0.3048 & meter \\
foot of water $(\mathrm{ft}$ of water $)$ & 22.4198 & millimeter of mercury \\
inch square per pound $\left(\mathrm{in}^{2} / \mathrm{lb}\right)$ & 0.000145 & meter square per Newton \\
$\operatorname{mile}(\mathrm{mi})$ & 1.6093 & kilometer \\
$\operatorname{millibar}(\mathrm{mb})$ & 0.10 & kilopascal \\
pound per square inch per foot $\left(\mathrm{lb} / \mathrm{in}^{2} / \mathrm{ft}\right)$ & 157.1092 & Newton per cubic meter \\
pound per square inch $\left(\mathrm{lb} / \mathrm{in}^{2}\right)$ & $6,896.55$ & Newton per square meter \\
reciprocal foot $\left(\mathrm{ft}^{-1}\right)$ & 3.2808 & reciprocal meter \\
& & \\
\hline
\end{tabular}

Altitudes in this report are referenced to the National Geodetic Vertical Datum of 1929 (NGVD of 1929), a geodetic datum derived from a general adjustment of the first-order level nets of the United States and Canada; formerly called "Mean Sea Level" or "Sea Level Datum of 1929." 


\title{
Determination of Barometric Efficiency and Effective Porosity, Boreholes UE-25 c\#1, UE-25 c\#2, and UE-25 c\#3, Yucca Mountain, Nye County, Nevada
}

\author{
By Arthur L. Geldon, John D. Earle, and Amjad M.A. Umari
}

\begin{abstract}
Simultaneous records of water-level altitudes in boreholes UE-25 c\#1, UE-25 c\#2, and UE-25 c\#3 (the C-holes) and atmospheric pressure at and near the C-holes were obtained from July 15 to September 8, 1993, to determine the barometric efficiency of the entire uncased section of each of the C-holes, for the purpose of analyzing pumping tests. Each of the C-holes is 3,000 feet deep. About 1,600 feet of each borehole is open in Miocene tuffaceous rocks. Water-level altitudes in the C-holes fluctuate in response to Earth tides and changes in atmospheric pressure, which are characteristics of wells completed in an elastic, confined aquifer. The barometric efficiency of the C-holes in this study was analyzed by filtering simultaneously collected water-level-altitude and atmosphericpressure data to remove the influences of Earth tides and semi-diurnal heating and cooling and then regressing filtered water-level-altitude changes as a function of filtered changes in atmospheric pressure. The average barometric efficiency of the uncased sections of boreholes UE-25 $\mathrm{c} \# 1$ and UE-25 $\mathrm{c} \# 3$ was determined to be 0.94 . Malfunctioning equipment prevented determining the barometric efficiency of borehole UE-25 c\#2. An average effective porosity of 0.36 was calculated from barometric efficiency values determined in this study and a specific storage value of $0.497 \times 10^{-6}$ per foot that was determined previously from geophysical logs of
\end{abstract}

the C-holes. A porosity of 0.36 is consistent with values determined from geophysical logs and core analyses for the Calico Hills Formation.

\section{INTRODUCTION}

The use of a multiple-well interference test (hereafter called a pumping test) to determine hydraulic properties of an aquifer requires that waterlevel-altitude changes in observation wells caused by stresses other than pumping be removed from waterlevel altitudes obtained during the test before the data can be analyzed (Bureau of Reclamation, 1981; Brassington, 1988). The most common extraneous stresses that can affect water-level altitudes in wells during pumping tests are changes in atmospheric pressure (barometric effects) and Earth tides (Ferris and others, 1962).

In this study, simultaneous records of

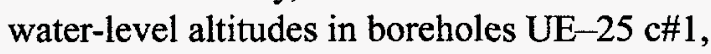
UE- $25 \mathrm{c} \# 2$, and UE-25 c\#3 (the C-holes), atmospheric pressure at borehole UE-25 $\mathrm{c} \# 3$ and a nearby weather station, WX-3, and Earth-tide dilatation at the C-hole complex were obtained from July 15 to September 8, 1993, at a time when the C-holes were not being pumped. During the study, no packers were emplaced in the C-holes. Consequently, data obtained were for the entire uncased section of each borehole, which averages about $1,600 \mathrm{ft}$.

This report discusses how Earth-tide effects and effects related to daily atmospheric heating and cooling were removed from recorded water-level altitudes in order to determine the barometric 
efficiency of the C-holes. As defined by Ferris and others (1962), the barometric efficiency is the ratio of the change in the water-level altitude to a concurrent change in atmospheric pressure. Multiplying the change in atmospheric pressure by the barometric efficiency and subtracting this product from the initial water-level altitude removes changes in the waterlevel altitude caused by barometric effects. The barometric efficiency determined after removal of Earth-tide and atmospheric heating and cooling effects relates water-level-altitude fluctuations in wells to atmospheric-pressure changes caused by the passage of weather systems. Barometric efficiency values determined in this study can be used to compute drawdown for the purpose of analyzing pumping tests in the C-holes when packers are not emplaced in these boreholes.

\section{LOCATION AND CONSTRUCTION OF THE C-HOLES}

The C-holes are located on the eastern flank of Yucca Mountain, between Bow Ridge and Fran Ridge, just east of the western boundary of the Nevada Test Site, about $90 \mathrm{mi}$ northwest of Las Vegas, Nev. (Geldon, 1993). Weather station WX-3, which is maintained by the U.S. Geological Survey as part of a meteorological monitoring network at Yucca Mountain (Flint and Davies, 1997), is located in Drill Hole Wash, about $3.3 \mathrm{mi}$ northwest of UE-25 c\#1. Surface coordinates and altitudes of the C-holes and station WX-3 are listed in table 1; locations of these sites are shown in figure 1.

Table 1. Surface coordinates and altitudes of the C-holes and weather station WX-3, Yucca Mountain, Nevada

\begin{tabular}{llllll}
\hline \multirow{2}{*}{ Site } & \multirow{2}{*}{ Latitude } & Longitude & \multicolumn{2}{c}{$\begin{array}{c}\text { Nevada } \\
\text { Central Zone }\end{array}$} & \multirow{2}{*}{$\begin{array}{c}\text { Altitude } \\
\text { (feet) }\end{array}$} \\
\cline { 3 - 4 } & & & North & East & \\
\hline UE-25 c\#1 & $36^{\circ} 49^{\prime} 47^{\prime \prime}$ & $116^{\circ} 25^{\prime} 43^{\prime \prime}$ & 757,096 & 569,680 & $3,709.28$ \\
UE-25 c\#2 & $36^{\circ} 49^{\prime} 46^{\prime \prime}$ & $116^{\circ} 25^{\prime} 43^{\prime \prime}$ & 756,849 & 569,634 & $3,714.49$ \\
UE-25 c\#3 & $36^{\circ} 49^{\prime} 45^{\prime \prime}$ & $116^{\circ} 25^{\prime} 44^{\prime \prime}$ & 756,910 & 569,555 & $3,715.25$ \\
WX-3 & $36^{\circ} 52^{\prime} 10^{\prime \prime}$ & $116^{\circ} 27^{\prime} 40^{\prime \prime}$ & 771,482 & 560,198 & $4,432.36$ \\
\hline \multicolumn{4}{l}{ 'Nevada Central Zone Coordinates are based on a Transverse } \\
Mercator projection. The origin of this projection is at latitude $34^{\circ} 45^{\prime}$ N., \\
longitude $116^{\circ} 40^{\prime}$ W.
\end{tabular}

The C-holes are 100 to $251 \mathrm{ft}$ apart at the land surface (fig. 1). Because of borehole deviation during drilling, interborehole distances at depth range from 94 to $283 \mathrm{ft}$. The C-holes were drilled in 1983 and 1984 to depths of 3,000 ft, but individual boreholes have collapsed 14 to $55 \mathrm{ft}$ since completion. Casing and concrete in the $\mathrm{C}$-holes extend 1,365 to $1,371 \mathrm{ft}$ below land surface, and uncased sections of individual boreholes range from 1,574 to $1,621 \mathrm{ft}$ in length.

Each of the C-holes intersects the Paintbrush Group, Calico Hills Formation, and Crater Flat Group (table 2). The tuffaceous rocks penetrated by the $\mathrm{C}$-holes are Miocene in age and estimated to be about $5,000 \mathrm{ft}$ thick. In the vicinity of Yucca Mountain, the tuffaceous rocks are underlain by thousands of feet of Paleozoic carbonate rocks (Frizzell and Shulters, 1990). The tuffaceous rocks penetrated by the C-holes are fractured and faulted (Geldon, 1996).

The top of the saturated zone at the $\mathrm{C}$-hole complex coincides approximately with the contact between the Paintbrush Group and the Calico Hills Formation (Geldon, 1996). Depths to water range from about $1,313 \mathrm{ft}$ below land surface in UE-25 c\#1 to about $1,319 \mathrm{ft}$ below land surface in UE-25 $\mathrm{c \#} 3$ (about 45-55 ft above the bottom of casing and concrete in each borehole). The average water-level altitude at the C-hole complex decreases southeastward, from about $2,396 \mathrm{ft}$ in $\mathrm{UE}-25 \mathrm{c \#} 3$ to about $2,395 \mathrm{ft}$ in $\mathrm{UE}-25 \mathrm{c \#}$.

\section{WATER-LEVEL-ALTITUDE MEASUREMENTS IN THE C-HOLES}

Water-level altitudes in the $\mathrm{C}$-holes were obtained with differential pressure transducers, which record changes in depth-of-submersion pressure as changes in electrical potential. The transducers used in this study (table 3 ) were installed, calibrated, connected to data loggers, and removed in accordance with procedures described by Lobmeyer and others (1995).

In accordance with procedures described by O'Brien (1991), depths to water in the C-holes (table 4) were measured with a reeled surveyor's chain as transducers were installed and removed. From the calibration and depth-to-water measurements, 

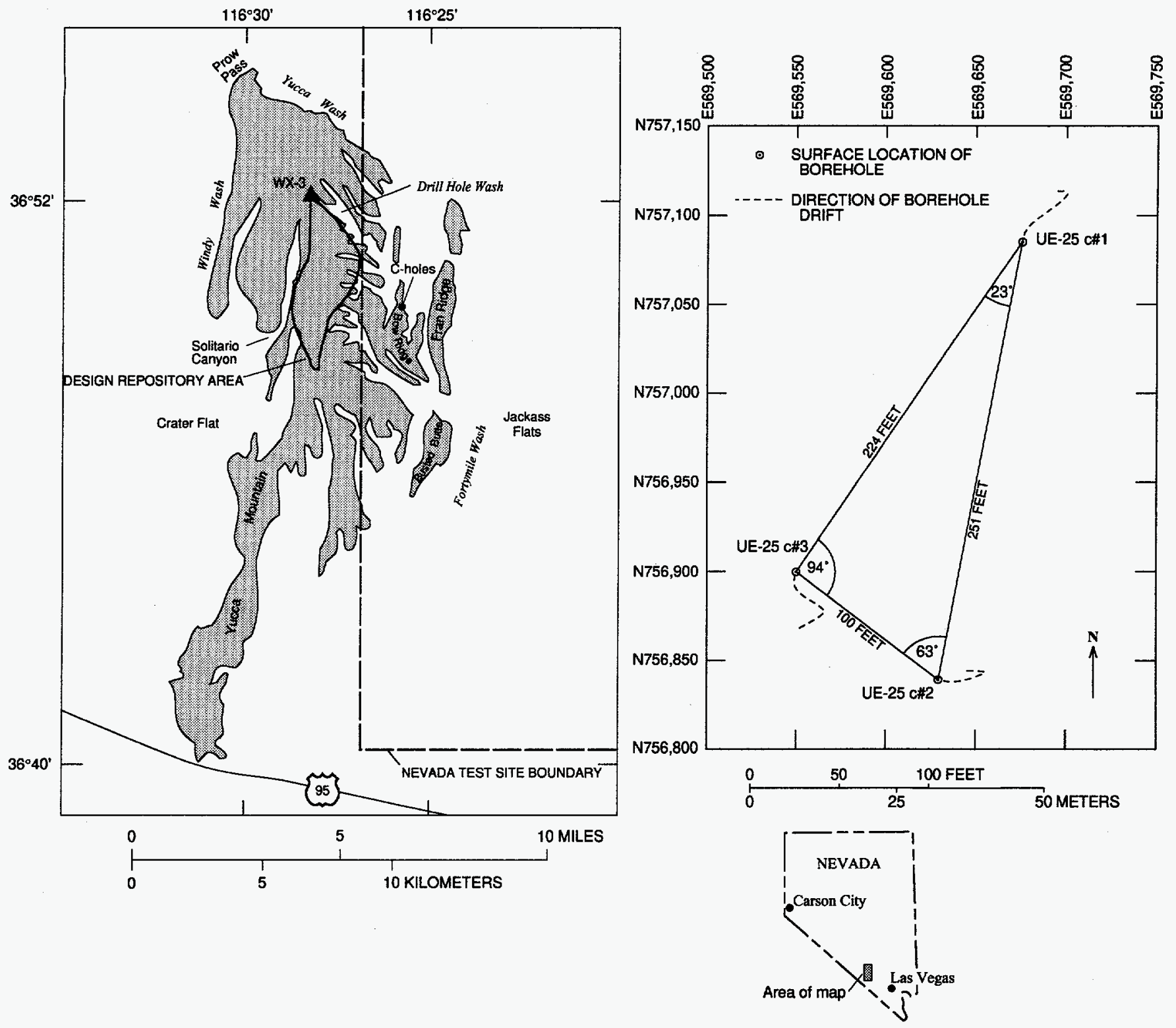

Figure 1. Location of boreholes UE-25 c\#1, UE-25 c\#2, and UE-25 c\#3 and weather station $W X-3$ at Yucca Mountain, Nevada.

equations were developed for each of the C-holes to convert transducer output, in millivolts, to depth to water, in feet. The general equation or converting transducer output to depth to water is:

$$
\mathrm{DTW}=\mathrm{DTM}_{\mathrm{m}}+\mathrm{S}-\mathrm{b}-\mathrm{m} \times \mathrm{E} ;
$$

where

DTW = calculated depth to water, in feet; $\mathrm{DTW}_{\mathrm{m}}=$ measured depth to water, in feet;
$\mathrm{S}=$ distance of transducer below the water level (the set point), in feet;

$\mathrm{b}=\mathrm{y}$-axis intercept, in feet, determined by regression of transducer submergence as a function of transducer output; $\mathrm{m}=$ slope, in feet per millivolt, determined by regression of transducer submergence as a function of transducer output; and

$\mathrm{E}=$ transducer output, in millivolts. 
Interpolation between equations 6 and 7 , over a period of 92.94 days, indicated the following equation to correct for transducer drift:

$$
\begin{aligned}
\text { DTW }= & 1,325.04-0.00839 \times \mathrm{t} \\
& -[(0.00734-0.000000646 \times t) \times \mathrm{E}]
\end{aligned}
$$

where all variables are as defined in equation 2.

A plot of the measured water-level altitude in UE-25 $\mathrm{cH} 2$ as a function of time elapsed since the initial transducer calibration shows no antecedent trend in the data, but, as in UE-25 c\#1, semidiurnal and longer fluctuations caused by Earth tides, atmospheric heating and cooling, and the movement of weather systems through the area are evident (fig. $3 B$ ). During the short period of reliable record, water-level altitudes in UE-25 $\mathrm{c} \# 2$ ranged from about $2,395.1$ to $2,395.6 \mathrm{ft}$ and averaged $2,395.28 \mathrm{ft}$.

\section{Borehole UE-25 c\#3}

A transducer record in hourly increments was obtained from borehole UE-25 c\#3 from 12:00 on July 15 to 09:00 on August 17, 1993. Despite erratic oscillations indicative of transducer malfunction, most of the 32.88-day record was considered reliable for conversion to water-level altitudes. The equation that was determined to convert transducer output to depth to water as the transducer was installed is:

$$
\mathrm{DTW}=1,325.37-0.00730 \times \mathrm{E}
$$

where all variables are as defined in equation 1.

The conversion equation that was determined when the transducer was removed is:

$$
\mathrm{DTW}=1,323.93-0.00724 \times \mathrm{E}
$$

where all variables are as defined in equation 1.

Interpolation between equations 9 and 10 , over a period of 110.03 days, indicated the following equation to correct for transducer drift:

$$
\begin{aligned}
\text { DTW }= & 1,325.37-0.0131 \times \mathrm{t} \\
& -[(0.0073-0.000000545 \times \mathrm{t}) \times \mathrm{E}]
\end{aligned}
$$

where all variables are as defined in equation 2 .

A plot of the measured water-level altitude in $\mathrm{UE}-25 \mathrm{c \#} 3$ as a function of time elapsed since the initial transducer calibration shows a slight antecedent decrease from about $2,396.1 \mathrm{ft}$ to about $2,395.4 \mathrm{ft}$ during the period of record (fig. 4). The average waterlevel altitude during this time was $2,395.74 \mathrm{ft}$. Semidiurnal and longer fluctuations caused by Earth tides, atmospheric heating and cooling, and the movement of weather systems through the area are evident in the water-level-altitude record.

\section{ATMOSPHERIC PRESSURE AT AND NEAR THE C-HOLES}

A record of atmospheric pressure in hourly increments was obtained at borehole UE-25 c\#3 from 12:00 on July 15 to $09: 00$ on August 17, 1993, using a nonsubmersible pressure transducer as a barometer. An absence of erratic readings during the 32.88-day period of record indicates that the barometer had no mechanical problems. Atmospheric pressures at UE-25 c\#3 during the period of record ranged from 29.5 to $30.0 \mathrm{ft}$ of water (fig. $5 \mathrm{~A}$ ) and averaged $29.72 \mathrm{ft}$ of water.

Although the barometer at borehole UE-25 c\#3 functioned perfectly for the intended analysis, it was disconnected inadvertently on August 17. Another barometric record was required to obtain a complete record of atmospheric pressure for the entire period in which water-level-altitude data were collected. At weather station $\mathrm{WX}-3$, about $3.3 \mathrm{mi}$ from and $715 \mathrm{ft}$ higher than the $\mathrm{C}$-holes, a recording barometer was in operation from July 15 to September 8, 1993 (Dale Ambos, Foothills Engineering Consultants, electronic commun., 1994). As shown in figure $5 A$, atmospheric pressures recorded at station WX-3, on the average, were about $0.75 \mathrm{ft}$ lower than pressures recorded at borehole UE-25 $\mathrm{c} \# 3$, but they fluctuated nearly synchronously. The two barometric records deviated only on August 9, when abrupt changes in the WX-3 barometer output, unmatched by changes in the UE- $25 \mathrm{c} \# 3$ barometer output and water-level altitudes in the $\mathrm{C}$-holes, indicate that the 

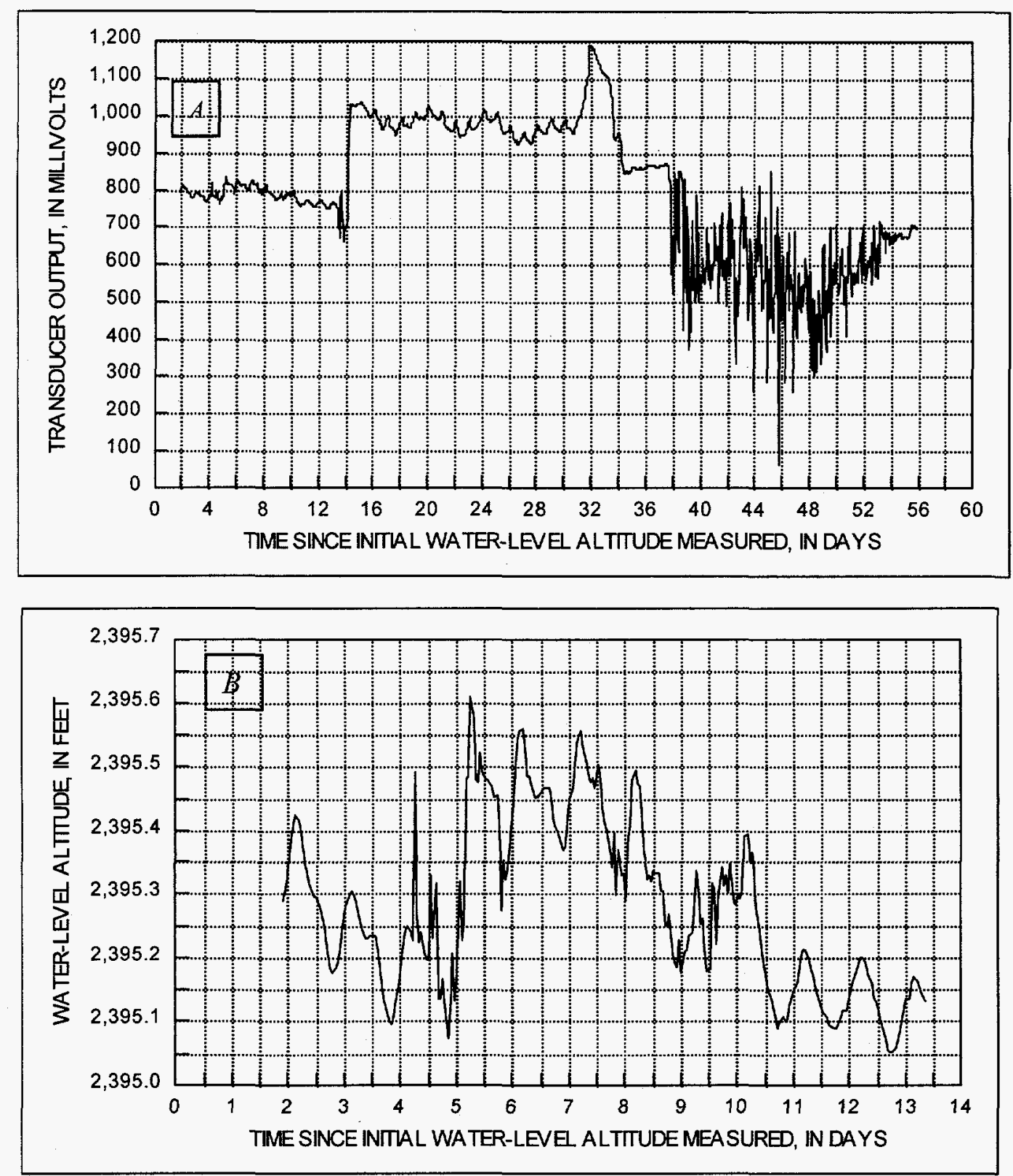

Figure 3. Borehole UE-25 c\#2, Yucca Mountain, Nevada: $A$, transducer output, July 15 to September 7, 1993; $B$, water-level altitudes, July 15 to $26,1993$.

WX -3 barometer malfunctioned. Regression of the UE-25 $\mathrm{c} \# 3$ barometric data as a function of the WX-3 barometric data, minus the data for August 9 (fig. $5 B$ ), indicated close correlation between the two barometric records (the correlation coefficient for this regression,

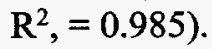
equation:

This regression produced the following

$$
\mathrm{P}_{\mathrm{chl}}=0.994 \times \mathrm{P}_{\mathrm{w} \times 3}+0.91
$$

where

$$
\begin{gathered}
P_{\mathrm{chl}}=\begin{array}{c}
\text { atmospheric pressure, in feet of water, at } \\
\text { UE }-25 \mathrm{c} \# 3 \text {; and }
\end{array} \\
P_{\mathrm{wx} 3}=\begin{array}{c}
\text { atmospheric pressure, in feet of water, at } \\
\text { WX-3. }
\end{array}
\end{gathered}
$$

Semi-diurnal and longer fluctuations caused by atmospheric heating and cooling and by the movement of weather systems through the area occur in the barometric records at both borehole UE $-25 \mathrm{c} \# 3$ and station WX-3. The semi-diurnal fluctuations typically 


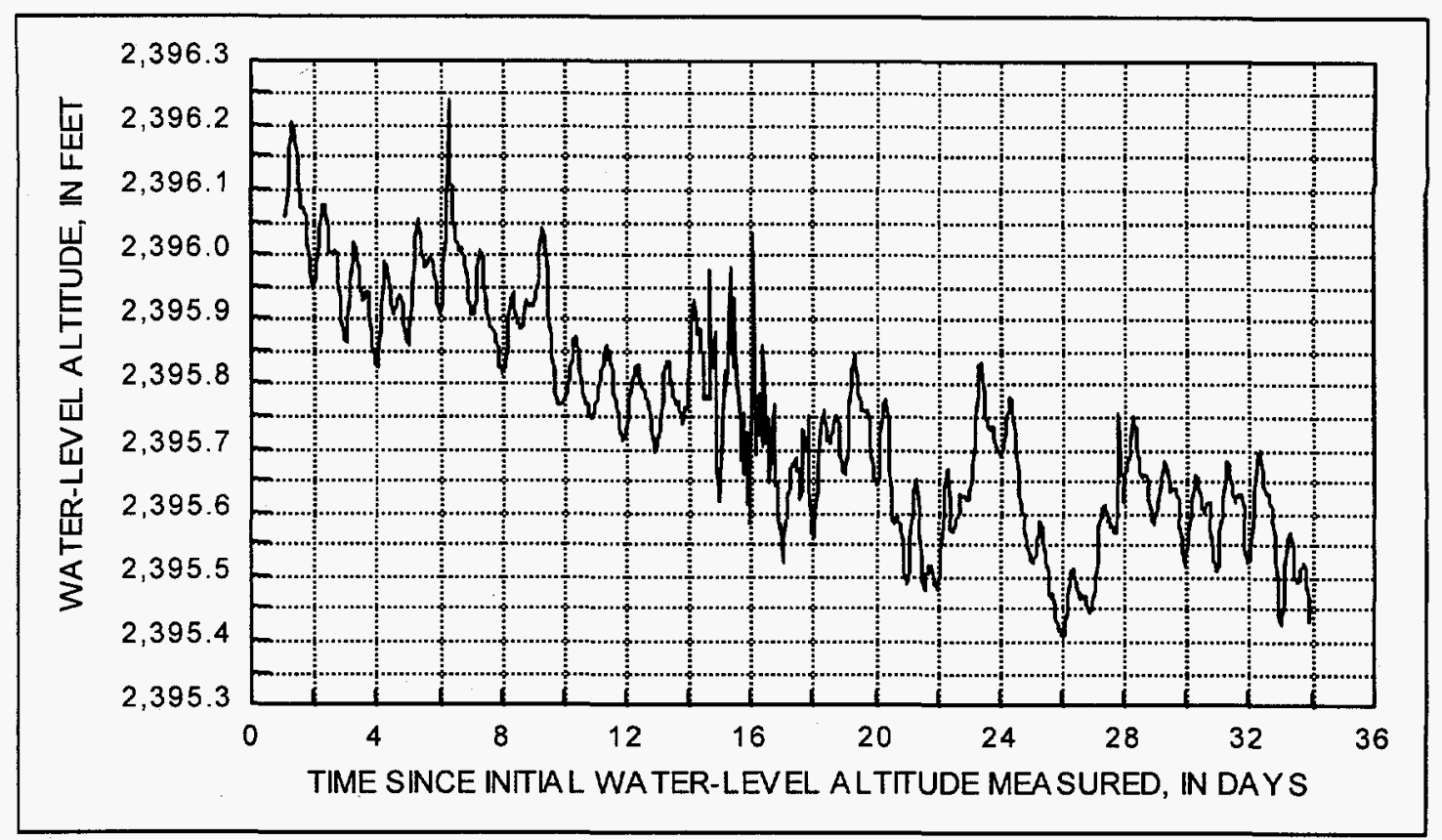

Figure 4. Water-level altitude in borehole UE-25 c\#3, Yucca Mountain, Nevada, July 15 to August 17, 1993.

range in magnitude from less than 0.01 to $0.15 \mathrm{ft}$. Daily peaks in atmospheric pressure typically occur between 06:00 and 10:00 and between 21:00 and 02:00, whereas daily troughs typically occur between 00:00 and 04:00 and between 16:00 and 19:00. Fluctuations in atmospheric pressure caused by the movement of weather systems typically range in magnitude from 0.2 to $0.4 \mathrm{ft}$ and have periods of 3 to 7 days. Many of the fluctuations in atmospheric pressure characteristically recorded at and near the C-holes are shown in figure 6 , a barometric record of two weather systems that moved through the area between August 24 and September 5, 1993. A plot of the water-level altitude in UE-25 $\mathrm{c \# 1}$ minus the mean water-level altitude in UE-25 $\mathrm{c \# l}$ on the same time axis as the mean atmospheric pressure at WX- 3 minus the atmospheric pressure at WX-3 (fig. 7) shows that water-level fluctuations in the $\mathrm{C}$-holes are influenced substantially by weather-system-related changes in atmospheric pressure.

\section{BAROMETRIC EFFICIENCY OF THE C-HOLES}

Barometric efficiency typically is obtained from an arithmetically scaled plot of waterlevel-altitude changes as a function of concurrent atmospheric-pressure changes over a sufficiently long period of time to represent the range in expected site conditions (see, for example, Bureau of Reclamation, 1981). The slope of a least-squares line fit through the data is the barometric efficiency. At the C-hole complex and sites throughout Yucca Mountain, this linear-regression method usually produces slopes greater than 1.0 (Richard R. Luckey, U.S. Geological Survey, written commun., 1995). Because the barometric efficiency cannot exceed 1.0 (Ferris and others, 1962), linear-regression slopes greater than 1.0 indicate that factors in addition to barometric effects influence waterlevel-altitude fluctuations at Yucca Mountain. Consequently, methods other than simple linear regression were used in the past and during the present investigation to determine the barometric efficiency of the C-holes.

\section{Previous Investigations}

The only previous investigation of barometric efficiency at the C-hole complex was done by Galloway and Rojstaczer (1988), using a 57-day record of water-level altitudes and atmospheric pressures obtained from February 23 to April 21, 1986. During this previous study, packers 

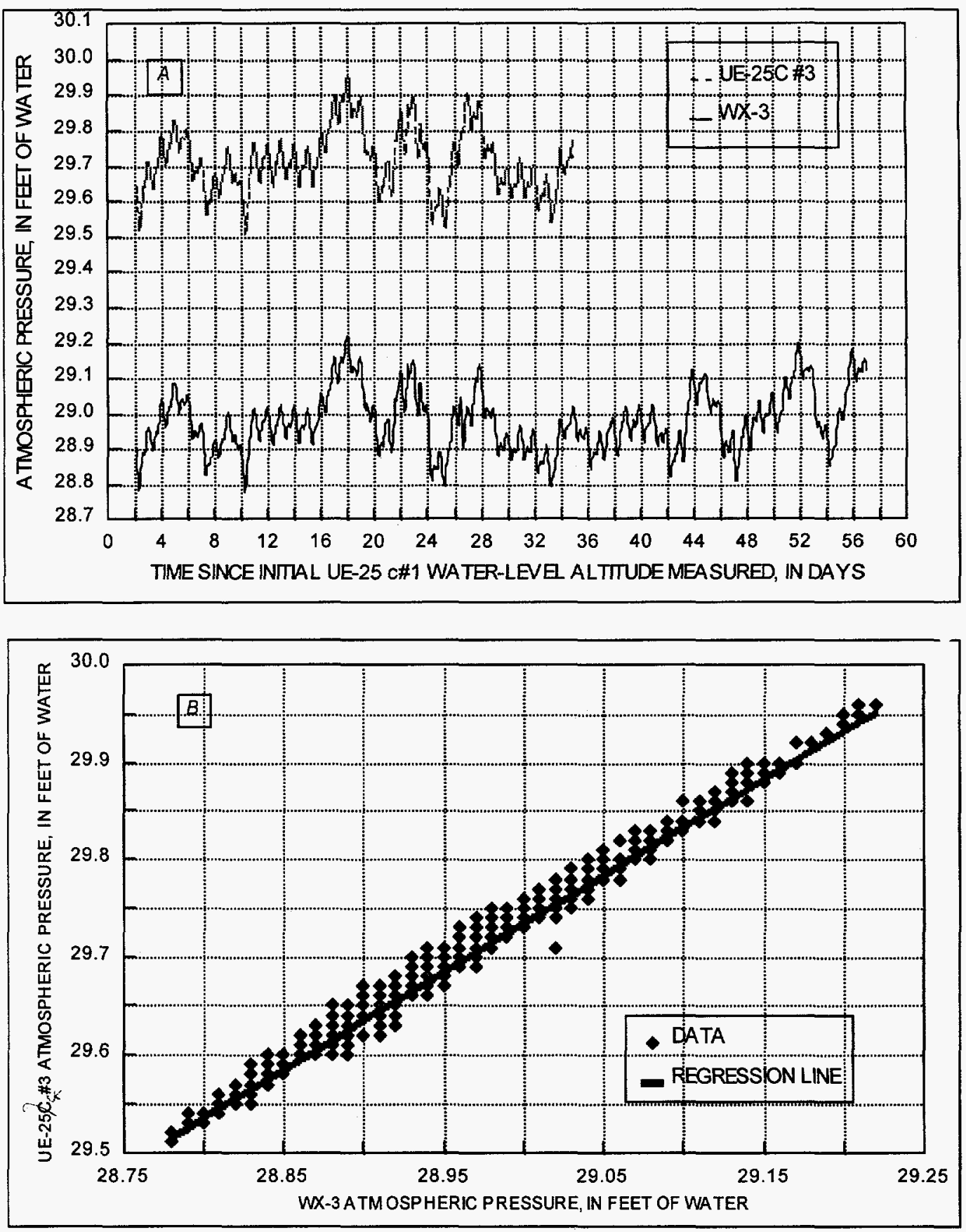

Figure 5. Relations of barometric records at borehole UE-25 $\mathrm{c} \# 3$ and weather station $W X-3$, Yucca Mountain, Nevada: $A$, concurrently recorded atmospheric pressures at UE-25 $\mathrm{cH}$ and WX-3, July 15 to September 8,$1993 ; B$, regression relation of UE-25 C\#3 barometric data as a function of $W X-3$ barometric data. 


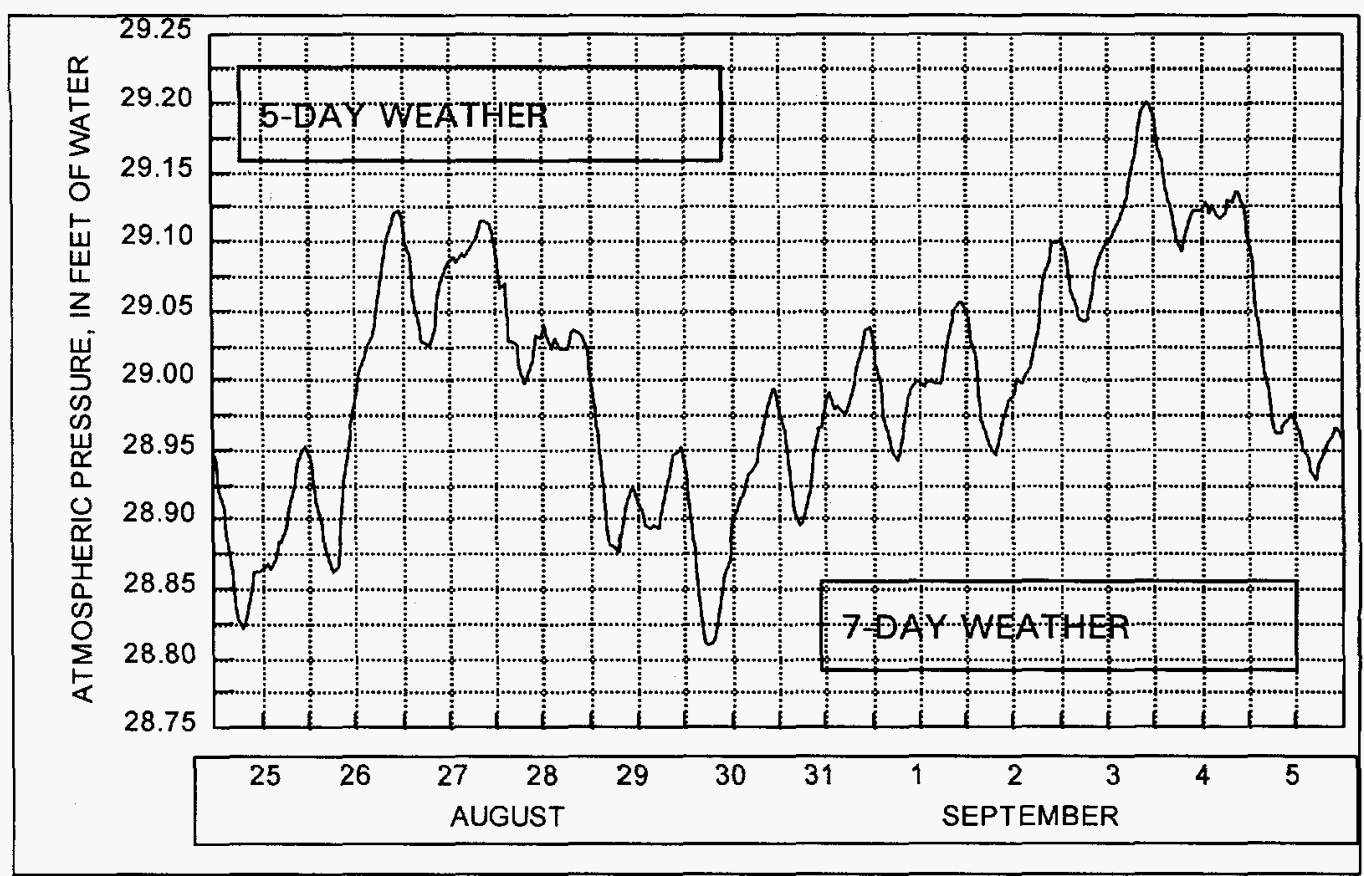

Figure 6. Atmospheric pressure at weather station $W X-3$, Yucca Mountain, Nevada, August 24 to September 5, 1993.

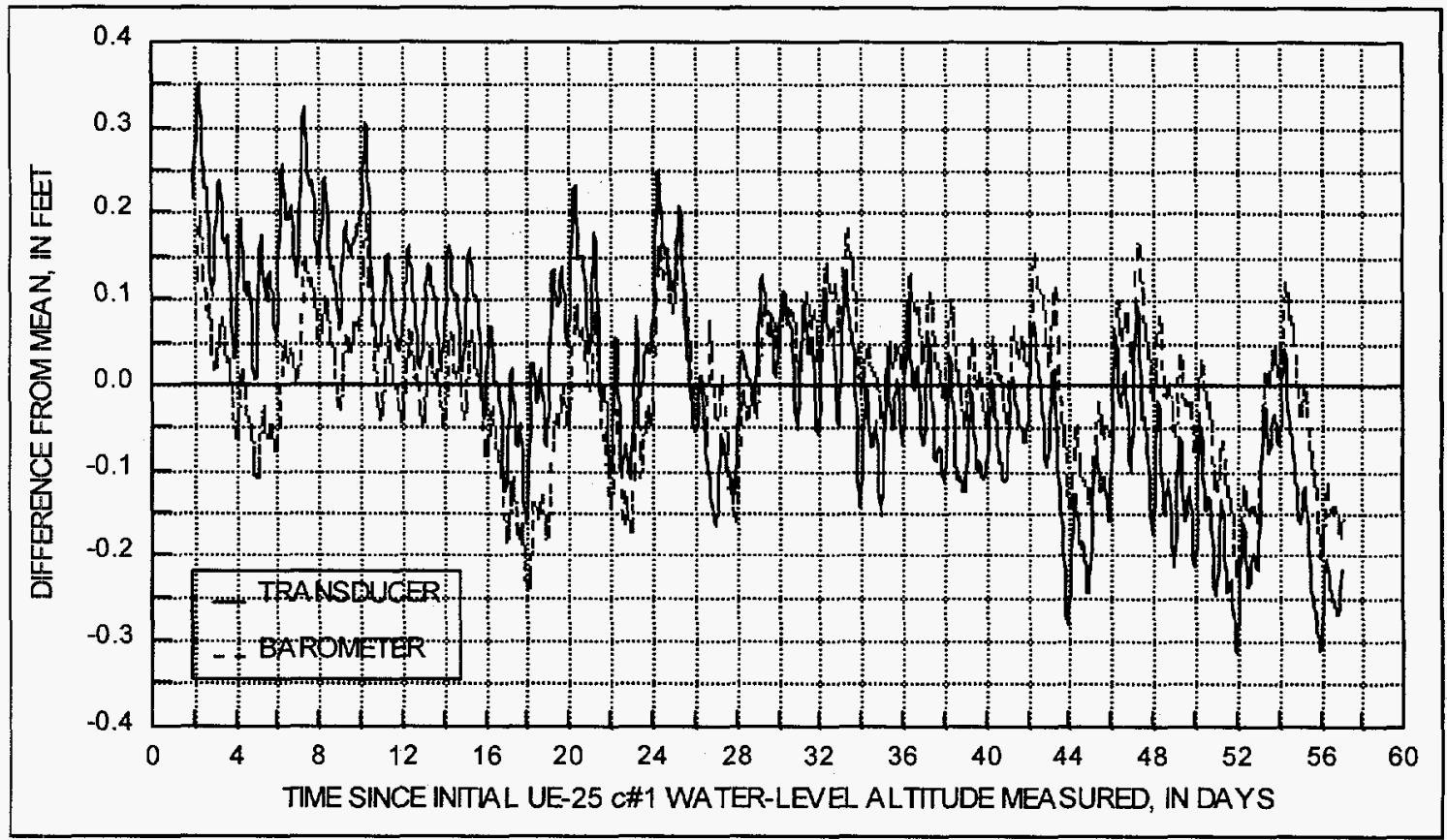

Figure 7. Effect of weather-system-related changes in atmospheric pressure on water-level altitudes in borehole UE-25 c\#1, Yucca Mountain, Nevada, July 15 to September 8, 1993. 
were emplaced in UE-25 c\#1 at a depth of $2,613 \mathrm{ft}$; in $\mathrm{UE}-25 \mathrm{c} \# 2$ at a depth of $2,477 \mathrm{ft}$; and in UE-25 c\#3 at a depth of 2,462 ft. Transducers in the packed-off intervals were vented to maintain contact with the atmosphere. Prior to analysis, long-term trends in the water-level-altitude and atmospheric-pressure data were removed by applying a high-pass filter with a cut-off frequency of 0.0009 cycles per day. For UE-25 c\#1, UE-25 c\#2, and UE-25 c\#3 above the packers and UE $-25 \mathrm{c} \# 3$ below the packer, transfer function gains (as defined by Quilty and Roeloffs, 1991) were plotted as a function of the dimensionless frequency of atmospheric-pressure fluctuations. The data curves were matched to curves for the theoretical frequency response of a partially confined aquifer to atmospheric loading. Barometric-efficiency values of 0.80 were determined for intervals above the packers, whereas a barometric-efficiency value of 0.87 was determined for UE- $25 \mathrm{c} \# 3$ below the packer. According to Devin L. Galloway (U.S. Geological Survey, oral commun., 1995), values of barometric efficiency determined during this study apply only to the packed-off intervals. Packers emplaced to isolate different intervals of rock probably would result in different determinations of barometric efficiency.

\section{Current Method of Analysis}

The analytical method used in this study implicitly considers Earth-tide effects, which can produce water-level-altitude fluctuations in wells open in confined aquifers (Ferris and others, 1962). Earth tides are caused by forces exerted on the Earth by the gravitational attraction of the Sun and the Moon. The five principal Earth tides have periods of 12.0 to 25.8 hours and frequencies of 0.9 to 2.0 cycles per day (table 5).

Table 5. Periods and frequencies of the principal Earth tides (Galloway and Rojstaczer, 1988)

\begin{tabular}{clcc}
\hline Tide & Type & $\begin{array}{c}\text { Period } \\
\text { (hours) }\end{array}$ & $\begin{array}{c}\text { Frequency } \\
\text { (cycles per } \\
\text { solar day) }\end{array}$ \\
\hline O1 & Lunar & 25.81934169 & 0.929535706 \\
K1 & Lunar-Solar & 23.93446961 & 1.002737909 \\
N2 & Lunar & 12.65834823 & 1.895981969 \\
M2 & Lunar & 12.42060121 & 1.932273614 \\
S2 & Solar & 12.00000000 & 2.000000000 \\
\hline
\end{tabular}

Earth tides calculated for the latitude, longitude, and altitude of the C-hole complex with a FORTRAN program developed by Harrison (1971) are shown for the period of this investigation in figure 8 . The Earth tides in figure 8 were computed on the assumption that dry tidal dilatation is a radial, compressive stress.

Because the principal Earth-tide frequencies range from 0.9 to 2.0 cycles per day, a low-pass Butterworth filter was used to remove frequencies of more than 0.8 cycles per day. Changes in the filtered water-level-altitude data, then, were plotted as a function of concurrent changes in the filtered atmospheric-pressure data. The slope of a leastsquares line fit through the plotted data was considered the barometric efficiency.

\section{Borehole UE-25 c\#1}

Applying a low-pass filter to the UE-25 c\#1 water-level-altitude data removed all semi-diurnal fluctuations and smoothed plotted water-level altitudes throughout the period of investigation. Figure 9 shows the difference between measured and filtered waterlevel altitudes for a representative part of the record, from July 15 to July 22,1993 . A plot of 1,276 filtered water-level-altitude changes as a function of filtered atmospheric-pressure changes from July 15 to September 8, 1993 (fig. 10), had a slope of 0.946, with an $R^{2}$ value of 0.86 . By definition, the slope of this plot indicates a barometric efficiency of 0.95 .

\section{Borehole UE-25 c\#3}

The water-level-altitude record for borehole UE-25 c\#3 contains several upward and downward spikes that apparently resulted from intermittent transducer malfunctions. Spikes occurred on July 20, 17:00; July 25, 19:00; July 28, 00:00, to August 1, 06:00; and August 10, 21:00, to August 11, 09:00. Most of the erratic water-level altitudes could be corrected by interpolation between reliable waterlevel altitudes, using the barometric record as a guide. However, the water-level-altitude record was unsalvageable July 28, 00:00 to July $30,12: 00$. The water-level-altitude record August 8, 15:00, to August 11,09:00, could not be used because of a combination of transducer and barometer malfunctions. 


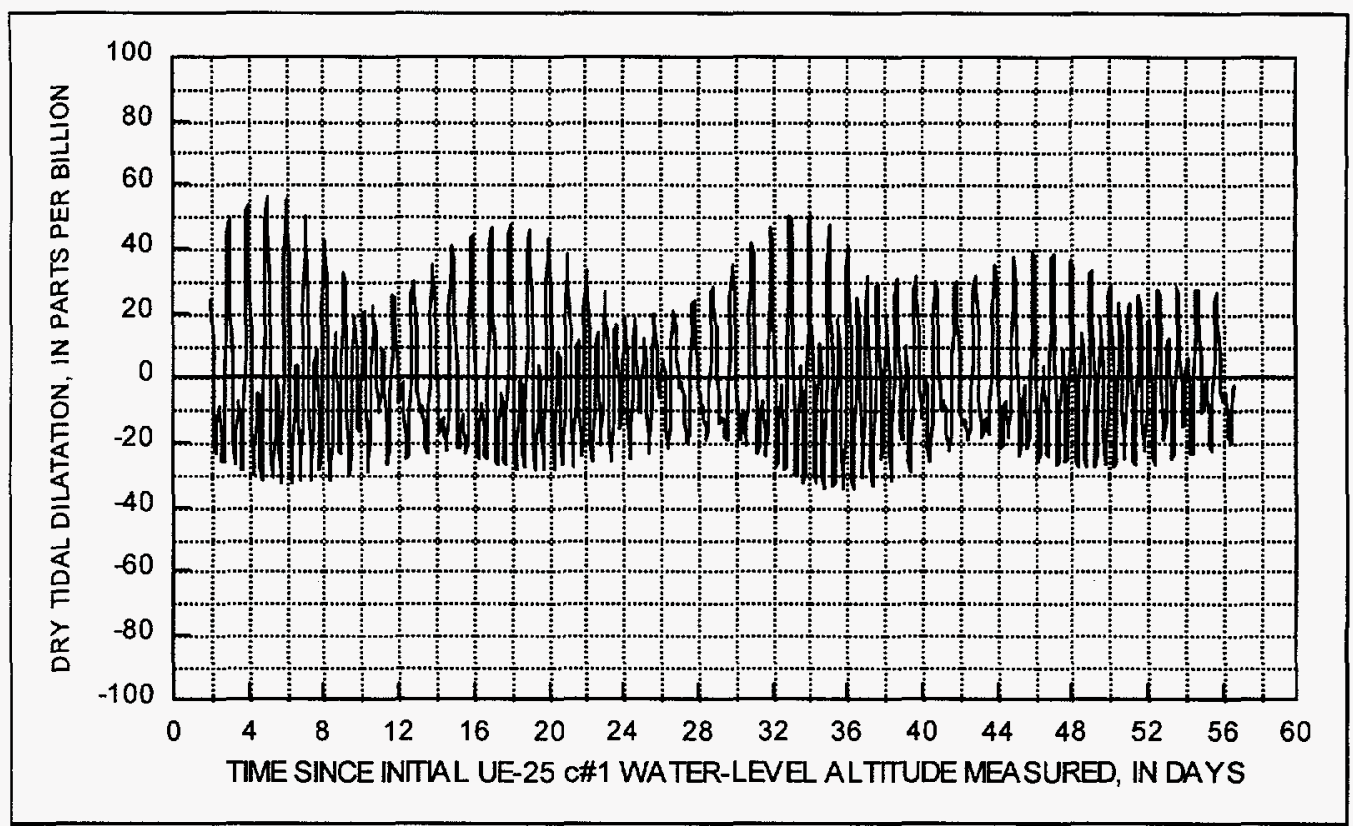

Figure 8. Calculated Earth tides at the C-hole complex, Yucca Mountain, Nevada, July 15 to September 7, 1993.

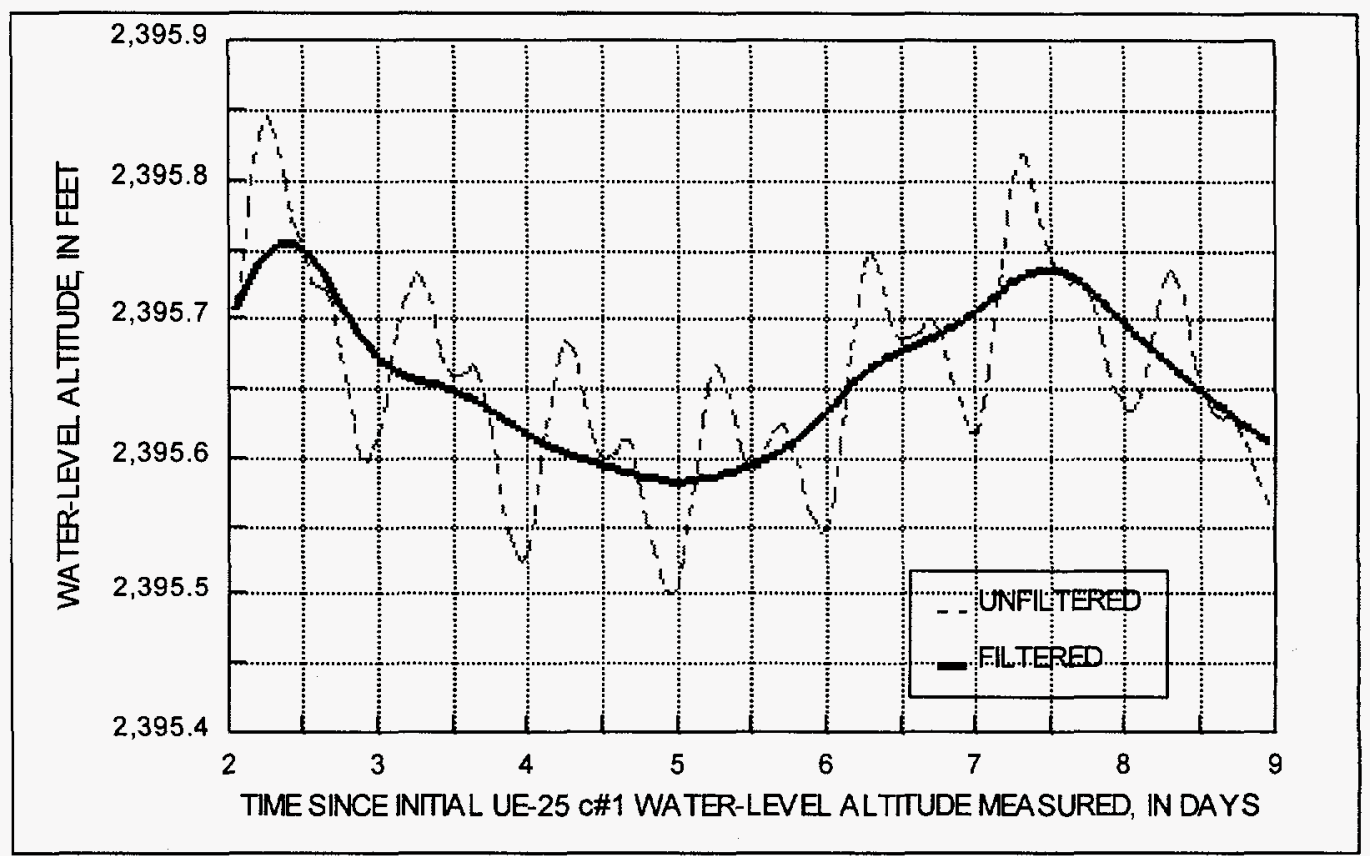

Figure 9. Measured water-level altitudes and water-level altitudes filtered for frequencies of less than 0.8 cycles per day, borehole UE-25 c\#1, Yucca Mountain, Nevada, July 15 to 22, 1993. 


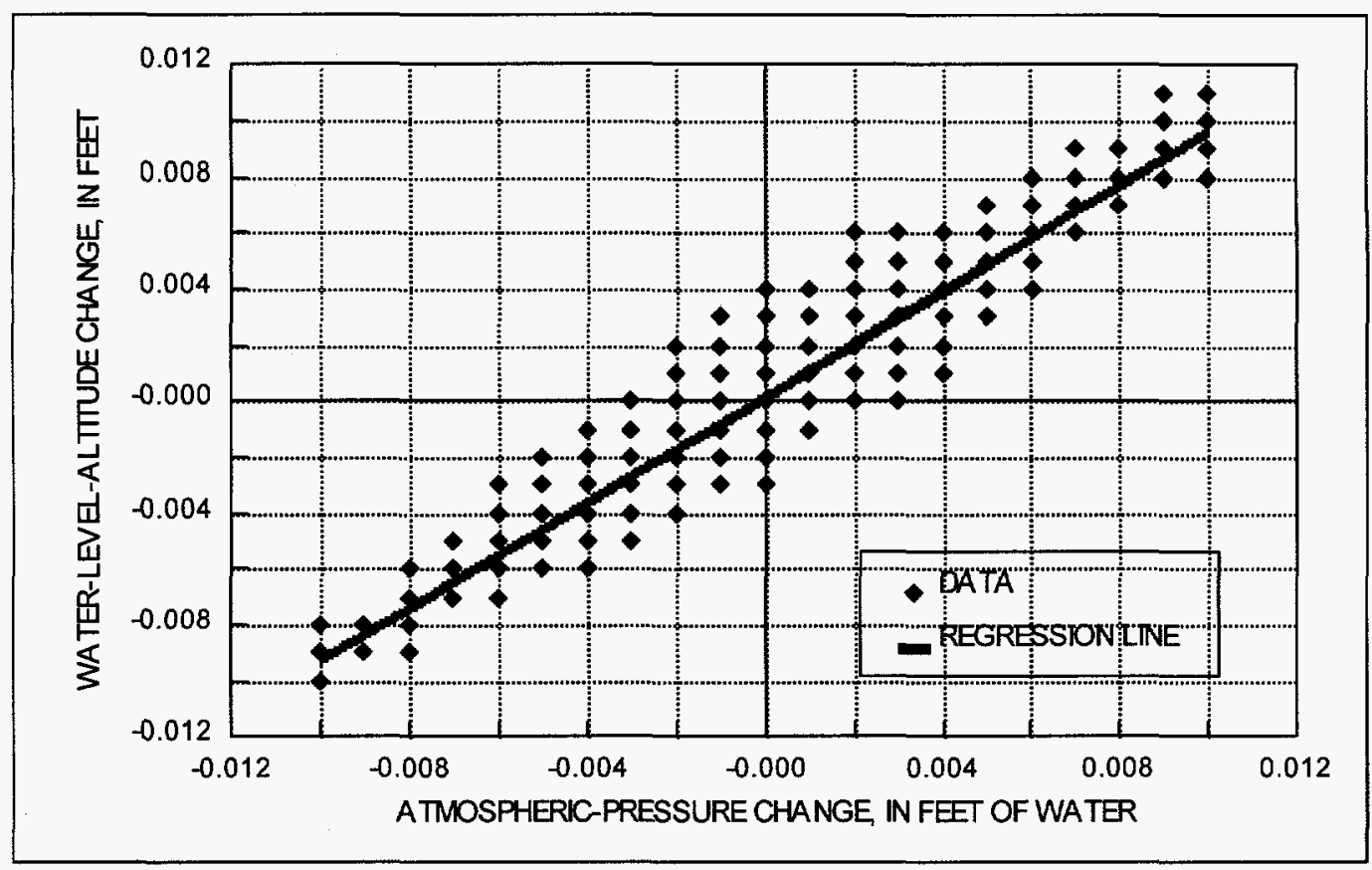

Figure 10. Relation of low-frequency water-level-altitude change in borehole UE-25 c\#1 to lowfrequency atmospheric-pressure change at station WX-3, Yucca Mountain, Nevada, July 15 to September 8, 1993.

Applying a low-pass filter to the UE-25 c\#3 water-level-altitude data removed all semi-diurnal fluctuations and smoothed plotted water-level altitudes throughout the period of reliable record. Figure 11 shows the difference between measured and filtered water-level altitudes for a representative part of the record, from July 15 to July 22, 1993. A plot of 661 filtered water-level-altitude changes as a function of filtered atmospheric-pressure changes for July 15 to 27, July 30 to August 9, and August 10 to 17,1993 (fig. 12) had a slope of 0.927 , with an $R^{2}$ value of 0.86 . By definition, the slope of this plot indicates a barometric efficiency of 0.93 .

\section{Verification Of Analytical Results}

Analyses of water-level-altitude data from boreholes UE-25 $\mathrm{c} \# 1$ and $U E-25 \mathrm{c} \# 3$ and atmospheric-pressure data from weather station WX-3 for the period July 15 to September 8, 1993, indicated barometric efficiency values of $0.93-0.95$ and an average barometric efficiency of 0.94 . The difference in barometric efficiency values obtained for boreholes UE-25 c\#1 and UE-25 c\#3 is so small that the average value is assumed to be the barometric efficiency of both boreholes. Moreover, it is assumed that this barometric efficiency applies to borehole UE-25 c\#2, because borehole UE-25 c\#2 penetrates the same geologic units as boreholes UE-25 c\#1 and UE-25 c\#3 and is constructed identically.

To verify the barometric efficiency value computed in this study, a correction for atmosphericpressure changes using a barometric efficiency of 0.94 was applied to water-level altitudes recorded in borehole UE-25 $\mathrm{c \# 1}$ during the passage of two prominent weather systems through the area from August 24 to September 5, 1993. As shown in figure 13, water-level altitudes in borehole UE-25 c\#1 fluctuated from 2,395.2 to 2,395.6 ft between August 24 and September 5, 1993. With the barometric correction applied, the fluctuation in water-level altitudes was reduced to about $0.1 \mathrm{ft}$. This dampening of water-level fluctuations indicates that the calculated barometric efficiency correctly compensates for the effects of Earth tides and atmospheric-pressure change. Consequently, figure 13 demonstrates that a barometric efficiency of 0.94 is acceptable for the C-holes without packers emplaced. 


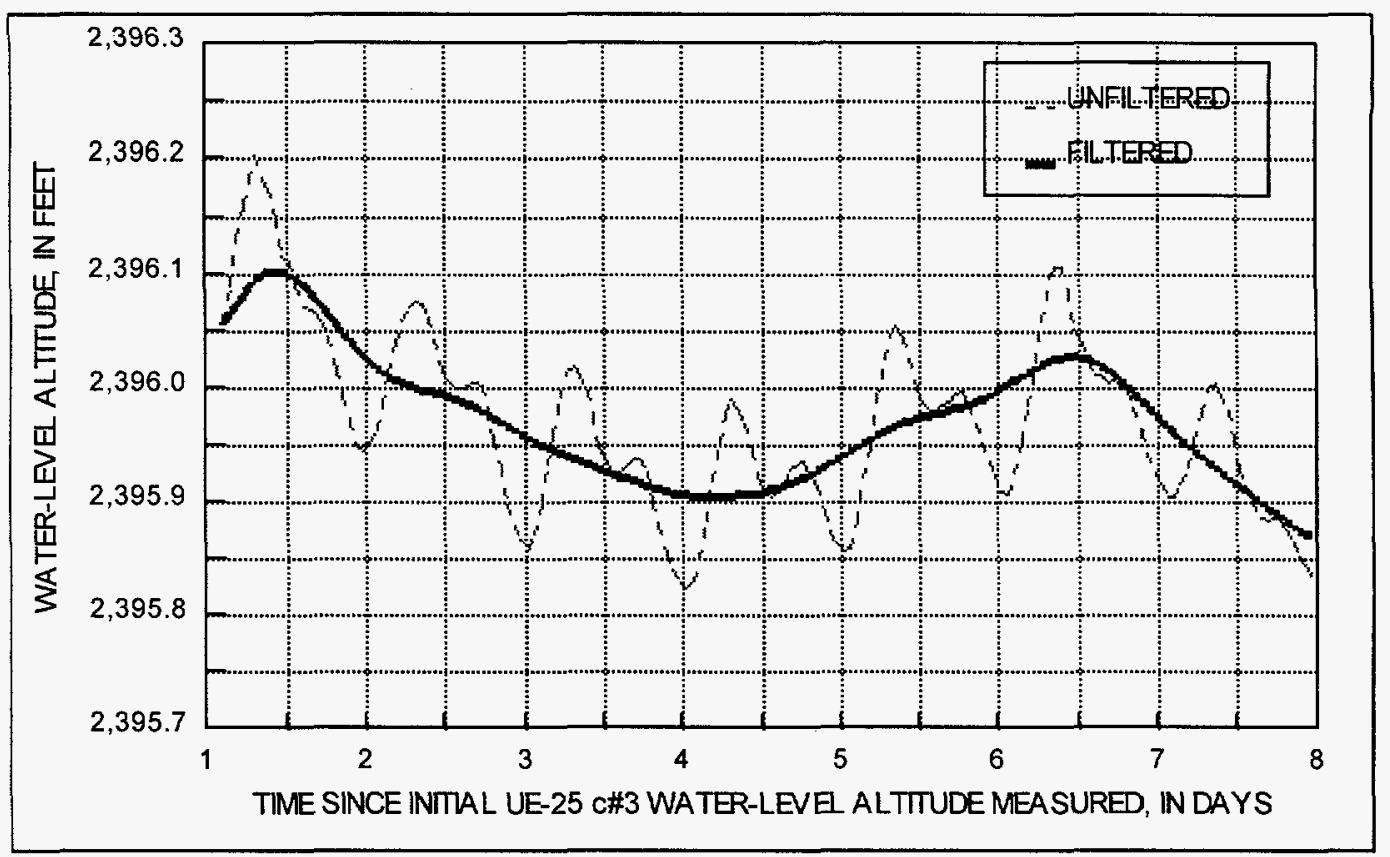

Figure 11. Measured water-level altitudes and water-level altitudes filtered for frequencies of less than 0.8 cycles per day, borehole UE-25 c\#3, Yucca Mountain, Nevada, July 15 to 22, 1993.

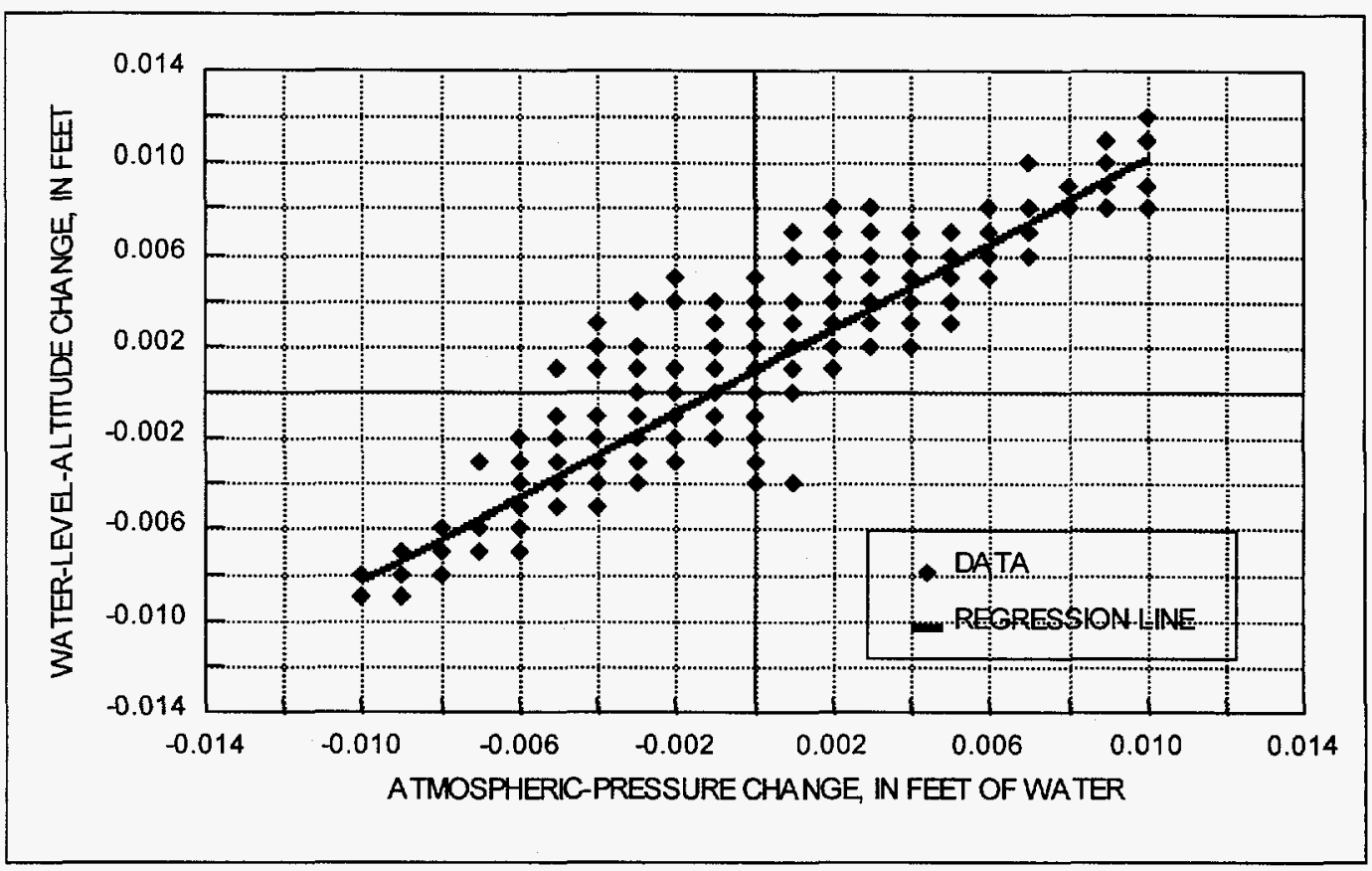

Figure 12. Relation of low-frequency water-level-altitude change in borehole UE-25 c\#3 to lowfrequency atmospheric-pressure change at station WX-3, Yucca Mountain, Nevada, July 15 to August 17, 1993. 


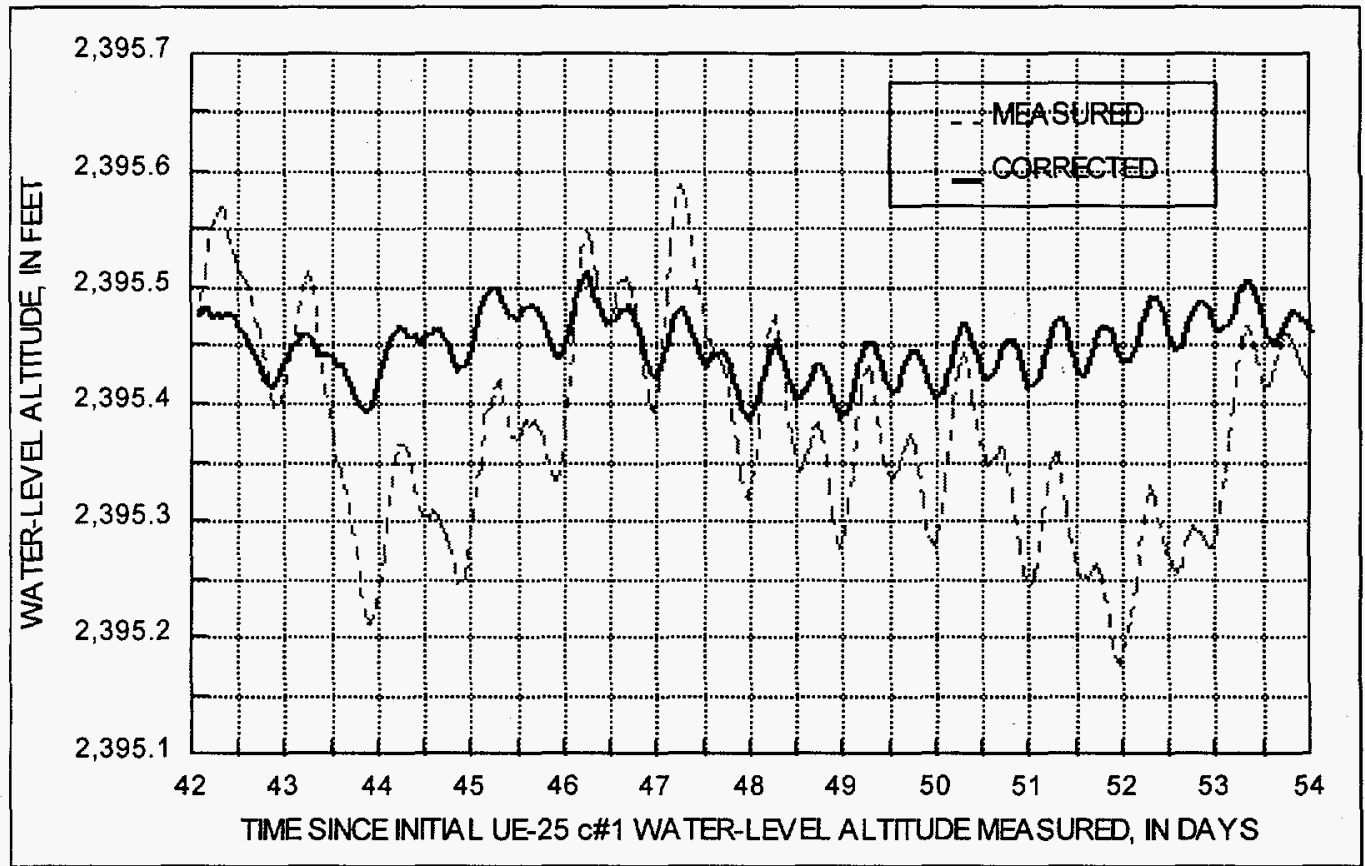

Figure 13. Measured water-level altitudes and water-level altitudes corrected for weathersystem-related changes in atmospheric pressure, borehole UE-25 c\#1, Yucca Mountain, Nevada, August 24 to September 5, 1993.

\section{EFFECTIVE POROSITY IN THE C-HOLES}

Confined aquifers and thick, unconfined aquifers respond to Earth tides and changes in atmospheric pressure because they are elastic (Lohman, 1979). In response to Earth tides and changes in atmospheric pressure, water is released from or taken into storage in an aquifer by compression or expansion of the aquifer skeleton and the volume of pore water (Ferris and others, 1962; Bredehoeft, 1967). Changes in the aquifer skeleton and the volume of pore water result in changes in water-level altitudes in a well that typically have an opposite sense to changes in Earth tides and atmospheric pressure.

The volume of water that an aquifer releases or takes into storage per unit volume of the aquifer per unit change in hydraulic head is called the specific storage (Bredehoeft, 1967). Specific storage is related to elastic properties of an aquifer and pore water by the following equation (modified from Lohman, 1979):

$$
\mathrm{S}_{\mathrm{s}}=\gamma(\beta \theta+1 / \mathrm{E})
$$

where

$\mathrm{S}_{\mathrm{s}}=$ specific storage (reciprocal feet);

$\gamma=$ specific weight of water $=0.434 \mathrm{lb} / \mathrm{in}^{2} / \mathrm{ft}^{-1}$;

$\beta=$ compressibility of water $=3.3 \times 10^{-6} \mathrm{in}^{2} / \mathrm{lb}$

(Lohman, 1979);

$\theta=$ porosity of aquifer skeleton (dimensionless); and

$\mathrm{E}=$ elasticity of aquifer skeleton (pounds per square foot).

Specific storage is related to barometric efficiency and effective porosity by the following equation (Jacob, 1940):

$$
\mathrm{S}_{\mathrm{s}}=\gamma \beta \theta / \mathrm{BE}
$$

where

$\mathrm{BE}$ = barometric efficiency (dimensionless), and all other variables are as defined in equation 13. 
After substituting constants given in equation 13 and rearranging equation 14 , effective porosity can be computed by the following equation:

$$
\theta=\left(\mathrm{S}_{\mathrm{s}} \times \mathrm{BE}\right) / 1.314 \times 10^{-6}
$$

The specific storage referred to in equations 13 to 15 is a scale-dependent property that cannot be determined from aquifer tests by dividing the calculated storativity by the test-interval thickness, because of factors other than the elastic properties of an aquifer that can affect these tests. Such factors include the flow of water through fractures and gravity drainage through pores. Geldon (1993) calculated values of specific storage for intervals in borehole UE-25 $\mathrm{c} \# 1$ that were based on geophysically determined porosity and elasticity values of the rocks in the borehole and physical properties of water that are stated in the explanation of equation 13. The thicknessweighted average of the specific-storage values calculated by Geldon (1993) is $0.497 \times 10^{-6} \mathrm{ft}^{-1}$, and if this value is assumed for the entire uncased thickness of the C-holes, then:

$$
\theta=\frac{0.497 \times 10^{-6} \times \mathrm{BE}}{1.314 \times 10^{-6}}=0.378 \times \mathrm{BE}
$$

Inserting barometric efficiency values determined in this study into equation 16 indicates values of effective porosity of 0.35 and 0.36 in boreholes UE- $25 \mathrm{c} \# 1$ and UE- $25 \mathrm{c} \# 3$. The average of these values is 0.36 .

Values of effective porosity determined in this study are interpreted to apply only to the basal Topopah Spring Tuff and the upper Calico Hills Formation, because the changes in water-level altitude from which the effective-porosity values were calculated occurred at this geologic horizon. Changes in the water table should be influenced strongly by matrix properties of the rock in which the water table is located. According to Geldon (1993), a gammagamma log of borehole UE-25 $\mathrm{c \# l}$ indicates that the average porosity of the upper Calico Hills Formation is $\mathbf{0 . 3 7}$, and a sample of core from this interval had a porosity of 0.38 . In contrast, the gamma-gamma log of $\mathrm{UE}-25 \mathrm{c \# 1}$ indicated average porosity values of 0.14 to 0.28 for most of the Prow Pass, Bullfrog, and Tram Tuffs (Geldon, 1993). The gamma-gamma log and core measurements verify that the effective-porosity values determined from this study are reasonable for the upper Calico Hills Formation.

\section{SUMMARY AND CONCLUSIONS}

Simultaneous records of water-level altitudes in the C-holes and atmospheric pressure at and near the C-holes were obtained from July 15 to September 8, 1993. This study was done to determine the barometric efficiency of the C-holes without packers emplaced in order to analyze pumping tests. Barometric-efficiency values obtained from this study were used to calculate the effective porosity of the rock in the $\mathrm{C}$-holes in which the water table is located.

Water-level altitudes in the $\mathrm{C}$-holes are affected by Earth tides and changes in atmospheric pressure associated with semi-diurnal atmospheric heating and cooling and the movement of weather systems through the area. Because the five principal solar and lunar tides have frequencies of 0.9 to 2.0 cycles per day, Earth-tide effects were removed from measured waterlevel-altitude fluctuations by filtering out frequencies of more than 0.8 cycles per day from the water-levelaltitude data. This process also removed semi-diurnal barometric effects from the water-level-altitude data. Frequencies of more than 0.8 cycles per day were filtered from the atmospheric-pressure data to be able to use water-level-altitude and atmospheric-pressure fluctuations with the same frequency range in computations.

The barometric efficiency of individual boreholes was determined by fitting a straight line to a plot of changes in filtered water-level altitude as a function of concurrent changes in filtered atmospheric pressure during the period of record. Barometricefficiency values for the C-holes were determined for a situation in which the $\mathrm{C}$-holes do not contain packers, and the entire uncased section of each borehole, therefore, communicates hydraulically with the atmosphere. Barometric efficiency was determined using a 55-day water-level record from borehole UE-25 c\#1, a 33-day water-level record from


pressure readings from weather station $\mathrm{WX}-3$ (3.3 mi northwest of the C-holes). 
Analyses of the available data indicated barometric-efficiency values of 0.93 and 0.95 and an average barometric efficiency of 0.94 for the C-holes. Adjusting water-level-altitude changes in borehole UE- $25 \mathrm{c \# 1}$ by using the computed average barometric-efficiency value dampened recorded waterlevel-altitude fluctuations substantially and verified the reliability of the analytical method and its results.

On the basis of barometric-efficiency values determined in this study and a specific-storage value of $0.497 \times 10^{-6}$ per foot, which was determined in a previous study, effective-porosity values of 0.35 and 0.36 were computed for rock in boreholes UE- $25 \mathrm{c \# 1}$ and $\mathrm{UE}-25 \mathrm{c} \# 3$. These porosity values are interpreted to apply only to the basal Topopah Spring Tuff and upper Calico Hills Formation. The water table at the $\mathrm{C}$-holes complex is located at this geologic horizon.

\section{REFERENCES}

Brassington, R., 1988, Field hydrogeology: New York, Halstead Press, 175 p.

Bredehoeft, J.D., 1967, Response of well-aquifer systems to Earth tides: Journal of Geophysical Research, v. 72, no. 12 , p. $3,075-3,087$.

Bureau of Reclamation, 1981, Ground water manual: Denver, Colo., $480 \mathrm{p}$.

Ferris, J.G., Knowles, D.B., Brown, R.H., and Stallman, R.W., 1962, Theory of aquifer tests: U.S. Geological Survey Water-Supply Paper 1536-E, 174 p.

Flint, A.L., and Davies, W.J., 1997, Meteorological data for water years 1988-94 from five weather stations at Yucca Mountain, Nevada: U.S. Geological Survey Open-File Report 96-462.

Frizzell, V.A., Jr., and Shulters, Jacqueline, 1990, Geologic map of the Nevada Test Site, southern Nevada: U.S. Geological Survey Miscellaneous Investigations Series Map I-2046, scale 1:100,000.
Galloway, Devin, and Rojstaczer, Stuart, 1988, Analysis of the frequency response of water-level altitudes in wells to Earth tides and atmospheric loading, in Hitchon, Brian, and Bachu, Stefan, eds., Proceedings fourth Canadian/American conference on hydrogeology, Fluid flow, heat transfer, and mass transport in fractured rocks: Dublin, Ohio, National Water Well Association, p. 100-113.

Geldon, A.L., 1993, Preliminary hydrogeologic assessment of boreholes UE-25c \#1, UE-25c \#2, and UE-25c \#3, Yucca Mountain, Nye County, Nevada: U.S. Geological Survey Water-Resources Investigation Report 92-4016, 85 p.

1996, Results and interpretation of preliminary aquifer tests in boreholes UE-25c \#1, UE-25c \#2, and UE-25c \#3, Yucca Mountain, Nye County, Nevada: U.S. Geological Survey Water-Resources Investigations Report 94-4177, 119 p.

Harrison, J.C., 1971, New computer programs for the calculation of Earth tides: Boulder, Colo., University of Colorado Cooperative Institute for Research in Environmental Sciences, $30 \mathrm{p}$.

Jacob, C.E., 1940, On the flow of water in an elastic artesian aquifer: American Geophysical Union Transactions, part 2, p. 574-586.

Lobmeyer, D.H., Luckey, R.R., O'Brien, G.M., and Burkhardt, D.J., 1995, Water levels in continuously monitored wells in the Yucca Mountain area, Nevada, 1989: U.S. Geological Survey Open-File Report 93-098, $173 \mathrm{p}$.

Lohman, S.W., 1979, Ground-water hydraulics: U.S. Geological Survey Professional Paper 708, $70 \mathrm{p}$.

O'Brien, G.M., 1991, Water-level altitudes in periodically measured wells in the Yucca Mountain area, Nevada, 1989: U.S. Geological Survey Open-File Report 91-178, 51 p.

Quilty, E.G., and Roeloffs, E.A., 1991, Removal of barometric pressure response from water level data: Journal of Geophysical Research, v. 96, no. B6, p. $10,209-10,218$. 